\title{
Penetration of solar UVB radiation in shallow tropical waters and its potential biological effects on coral reefs; results from the central Indian Ocean and Andaman Sea
}

\author{
Richard P. Dunne, Barbara E. Brown* \\ Department of Marine Science and Coastal Management, University of Newcastle, Newcastle upon Tyne NE1 7RU, \\ United Kingdom
}

\begin{abstract}
This paper presents the first complete data of global downwelling irradiance $\left(E_{\mathrm{d}}\right)$ and the diffuse attenuation coefficient $\left(K_{\mathrm{d}}\right)$ for solar ultraviolet-B $(U V B, 280$ to $320 \mathrm{~mm}$ ) in tropical waters. The penetration of solar UVB into shallow $(0$ to $5 \mathrm{~m}$ ) seawater at 3 sites in the central Indian Ocean and Andaman Sea, adjacent to areas of coral reefs, was studied using a semi-submersible scanning spectroradiometer. Downwelling global spectral irradiance $\left(E_{\mathrm{d}}\right)$ was measured at $2 \mathrm{~nm}$ intervals over the wavebands $280-320 \mathrm{~nm}$ (LVB), 320-400 nm (UVA) and $400-700 \mathrm{~nm}$ (PAR) above the sea surface $\left(0^{+} \mathrm{m}\right.$ ) and at each of 5 depths $(1,2,3,4$, and $5 \mathrm{~m})$. The 3 sites consisted of an ocean atoll in the Maldives (central Indian Ocean), a small $\left(8 \mathrm{~km}^{2}\right)$ high island $11 \mathrm{~km}$ off the continental coastline at Phuket, Thailand (Andaman Sea), and an inshore reef at Phuket. $E_{d}$ at each of the depths was integrated over the wavebands as a percentage of the above-water irradiance. $E_{\mathrm{d}}(\mathrm{UVB})$ at $5 \mathrm{~m}$ depth was found to decrease to $12 \%$ of incident inradiance at the mid-ocean atoll, to $2 \%$ for the high island site, and to $0.4 \%$ in the turbid waters of the inshore reef. A $1 \% E_{0}(\mathrm{UVB})$ depth was computed for each site and found to be 11,6 , and $3 \mathrm{~m}$ respectively. The diffuse attenuation for downwelling irradiance $\left(K_{\mathrm{d}}\right)$ for the depth range $0^{-} \mathrm{m}$ (just below the surface) to $5 \mathrm{~m}$ showed a very rapid attenuation with decreasing wavelength in the UVB at all sites. Biological damage potential, as weighted by the DNA-damage action spectrum, showed a more rapid attenuation with depth than $E_{\mathrm{d}}(\mathrm{UVB})$, with a $1 \% E_{\mathrm{DNA}}$ depth of $9 \mathrm{~m}$ for the ocean atoll, $4.7 \mathrm{~m}$ for the coastal island, and $2.6 \mathrm{~m}$ for the inshore reef
\end{abstract}

KEY WORDS: Coral reefs · Diffuse attenuation coefficient - Solar ultraviolet radiation UVB

\section{INTRODUCTION}

There is a common conception that coral reefs generally occur in clear oligotrophic waters of the tropical oceans. Whilst many reefs exist close to deep oceanic waters which are low in nutrients and phytoplankton and exhibit great visual clarity, it would be misleading to assume that such conditions are a prerequisite for reef growth. In the Pacific and Indian Oceans, for example, extensive reefs are found around land masses particularly in South East Asia, where high levels of phytoplankton production and other factors such as

·Addressee for correspondence. E-mail: b.e.brown@ncl.ac.uk rainfall run-off contribute to elevated levels of nutrients, sediments and dissolved organic material.

As a result of this common conception it is often stated or inferred that biologically damaging wavelengths of ultraviolet radiation (UVR) penetrate to considerable depths in waters supporting coral reefs (Falkowski et al. 1990, Gleason 1993, Shick et al. 1995, Lesser 1996). Detailed examination of the evidence supporting this statement, however, does not justify the apparent importance which seems to have become attached to it.

Although there are now quite extensive measurements of the longer UVR wavelengths (down to $350 \mathrm{~nm}$ ), accurate measurements of UVB (and UVA 
below $350 \mathrm{~nm}$ ) are few and data for tropical waters practically non-existent. To our knowledge the only accurate published data available are those of Smith \& Baker $(1979,1981)$ who measured UVR down to $310 \mathrm{~nm}$ in deep water in the Gulf of Mexico and at Tampa, Florida (USA), $30 \mathrm{~km}$ offshore, and to $300 \mathrm{~nm}$ in remote open ocean areas. This paucity of data is not surprising given the considerable measurement difficulties involved. Use of the only commercially available submersible scanning spectroradiometer, the LiCor Inc. LI-1800UW, for measurements below $320 \mathrm{~nm}$ is complicated by its wide bandwith ( $8 \mathrm{~nm})$ and the consequent need to transform readings using laborious algorithms (Webb 1985), a problem not likely to have been appreciated by those who have used it for UVB measurements. Additionally, single monochromators such as the LI-1800UW can suffer stray light problems in the UVB which limit their sensitivity and may give rise to spurious readings. Use of any scanning spectroradiometer for UVB measurements also requires extreme care in instrument calibration (Webb et al. 1994), or intercalibration where data is compared between different instruments (Gardiner et al. 1993). Broad-band non-scanning submersible UVB sensors are prone to substantial errors as a consequence of spectral changes in UVR with depth and water type (Kirk et al. 1994, authors' unpubl. data). Other techniques which have been used such as polymer films (Fleischmann 1989) primarily measure the longer wavelength UVA and therefore give a false impression of the penetration of the damaging shorter wavelengths. There is an overwhelming need, therefore, for accurate information on the underwater penetration of UVB around coral reefs.

In the present study we measured the downwelling global spectral irradiance of solar radiation underwater using scanning spectroradiometry in shallow tropical waters adjacent to areas of coral reefs, and at sites ranging from a mid-ocean atoll to turbid coastal waters. This paper summarises the results of our work with particular emphasis on the attenuation of UVB and discusses some of the biological consequences for corals. Choice of sites was limited by logistical considerations and the need for detailed background knowledge of each location. The depth range was constrained by the semi-submersible nature of the instrument used.

\section{MATERIALS AND METHODS}

Site location and conditions at time of measurements. Measurements were taken at 3 locations in the central Indian Ocean and Andaman Sea. The first location was in the lagoon of the mid-ocean atoll island of Furanafushi in the Republic of the Maldives $\left(4^{\circ} 14.98^{\prime} \mathrm{N}, 73^{\circ} 32.44^{\prime} \mathrm{E}\right)$. The lagoon bottom was at a depth of about 10 to $14 \mathrm{~m}$ and consisted of coarse white coral sand visible from the surface; water colour was deep blue. Recordings were commenced at 09:45 h (sun altitude $48^{\circ}$ ) and completed at $13: 56 \mathrm{~h}\left(59^{\circ}\right)$ on 7 July 1994. Maximum sun altitude was $72^{\circ}$ The water surface was almost completely calm, the sky was clear in the immediate vicinity of the sun throughout each scan sequence, some thin high cirrus clouds were present in other sky areas and there were approximately $1 / 10$ low horizon clouds. Furanafushi itself is a low (3 to $4 \mathrm{~m}$ elevation) vegetated sand island about $0.5 \times$ $0.5 \mathrm{~km}$ in extent situated on the east side of North Malé Atoll and is subject to a steady NE current of about 1 knot which brings clear oceanic seawater directly into the lagoon. The island has been developed as a tourist resort but any waste-water is discharged into a deep water channel to the south, clear of the measurement site. The reef structure around the island is similar to that for Tulusdu on its western oceanic side (described by Mateucci \& Russo 1985). On the eastern (atoll lagoon) side, the shallow reef community is dominated by coral genera which include Porites, Pocillopora, Acropora, Platygyra, Goniastrea, Favia and Favites, and which is typical of that described for ring reefs or faros in North Malé Atoll (Brown \& Dunne 1988).

The second location was adjacent to the Phuket Marine Biological Center (PMBC) (Thailand) pier $\left(7^{\circ} 48^{\prime} \mathrm{N}, 98^{\circ} 24.5^{\prime} \mathrm{E}\right)$. Measurements were taken in a water depth of $9 \mathrm{~m}$ over a bottom (not visible) of fine clay sediment of terrigenous origin. Recordings were commenced at $10: 08 \mathrm{~h}$ (sun altitude $46^{\circ}$ ) and completed at $15: 55 \mathrm{~h}\left(37^{\circ}\right)$ on 10 February 1995 . Maximum sun altitude was $68^{\circ}$. There was a light breeze causing a slight $(5 \mathrm{~cm})$ chop on the water surface; the sky was perfectly clear with no detectable haze. The site is immediately adjacent ( $30 \mathrm{~m}$ distance) to a $200 \mathrm{~m}$ broad fringing reef. The water is highly turbid and coloured distinctively green and probably represents one of the most extreme conditions where active coral growth takes place in the South East Asian region.

The final location was at Ko Racha Yai island $\left(7^{\circ} 36.75^{\prime} \mathrm{N}, 98^{\circ} 22.5^{\prime} \mathrm{E}\right) 11 \mathrm{~km}$ off the coast of Phuket. The site was in a bay on the NW side of the island in water depth of 13 to $14 \mathrm{~m}$ over a bottom of coarse calcareous sediment with moderate coral cover on basaltic rock (visible from the surface). Recordings were commenced at 10.54 h (sun altitude $58^{\circ}$ ) and completed at $14: 45 \mathrm{~h}\left(54^{\circ}\right)$ on 21 February 1995. Maximum sun altitude was $72^{\circ}$. The water surface was lightly rippled; weather conditions improved from extensive and variable cloud cover in the early morning to clear skies in the afternoon but with light cirrus and cumulus clouds on the horizon. Scans were only 
taken during periods when the sun was unobscured by clouds or haze. The water although clear had a noticeable green tinge. The island is comprised of rock of igneous origin, rising to a maximum elevation of $200 \mathrm{~m}, 4 \times 2 \mathrm{~km}$ in extent. It is visited by boat traffic but free of other anthropogenic influence. Both the Ko Racha Yai and the PMBC reef sites are described in Scoffin et al. (1992)

Measurement of downwelling irradiance. All measurements were made using a Macam Photometrics Ltd (Livingston, Scotland) SR9910 spectroradiometer. Input optics consisted of a $2 \pi$ cosine corrected PTFE (poly tetra fluoro ethylene) diffuser and an in-line $9 \mathrm{~m}$ quartz fibre optic. Cosine error was between $0 \%$ and $+1.5 \%$ to $75^{\circ}$. All underwater readings were corrected for immersion effect (Tyler \& Smith 1970) (maximum uncertainty of correction factor $\pm 5 \%$ at $95 \%$ confidence level; 280 to $700 \mathrm{~nm}$ ). The spectroradiometer is a double monochromator (concave holographic grating) with bandwidth $2 \mathrm{~nm}$; wavelength repeatability $\pm 0.5 \mathrm{~nm}$; absolute accuracy $\pm 5 \%$; stray light $<2 \times 10^{-8}$. The detector is a Hamamatsu $S 20$ (R 928) photomultiplier tube (PMT). Ambient temperatures $\left(29\right.$ to $34^{\circ} \mathrm{C}$ ) at field sites in Thailand were found to degrade both spectroradiometer sensitivity and stability, and at these locations the spectroradiometer was operated in an insulated container cooled by ice. Instrument sensitivity was $6 \times 10^{-5} \mathrm{~W} \mathrm{~m}^{-2} \mathrm{~nm}^{-1}$ at $320 \mathrm{~nm}$ rising to $1.1 \times 10^{-4} \mathrm{~W} \mathrm{~m}^{-2} \mathrm{~nm}^{-1}$ at $280 \mathrm{~nm}$. The spectroradiometer was calibrated before and after measurements against $20 \mathrm{~W}$ secondary deuterium and quartz halogen lamps traceable to National Physical Laboratory (UK) standards; the uncertainty of the calibration lamps was $\pm 5 \%$. Stray light checks were made using a $2 \mathrm{~mm}$ Schott WG320 filter. Wavelength accuracy was measured using mercury emission lines at $302.2,312.6,334$, and $365 \mathrm{~nm}$ in the ultraviolet; systematic errors were $+0.3,+0.65,+0.75$, and $+0.5 \mathrm{~nm}$ respectively at these wavelengths. Data were not corrected for the systematic errors.

In the field, all scans were made between 280 and $700 \mathrm{~nm}$ with a $2 \mathrm{~nm}$ step length. At Furanafushi, measurement at each step involved a 40 ms sampling time with 100 PMT analogue to digital conversions (ADC). In Thailand the spectroradiometer had been reprogrammed to $80 \mathrm{~ms}, 200$ ADC sampling. These sampling times were selected to minimise the effect of water surface wave glitter which has a dominant frequency of 2 to $2.5 \mathrm{~Hz}$ at $1 \mathrm{~m}$ depth, and $1 \mathrm{~Hz}$ at $5 \mathrm{~m}$ (Fraser et al. 1980). Scanning time was approximately $3 \mathrm{~min}$. Sequential scans were made above the water surface, and at $1,2,3,4$, and $5 \mathrm{~m}$ depth $( \pm 15 \mathrm{~cm})$. Before taking above water scans, the diffuser was rinsed in fresh water and dried to remove dirt or dried salt deposits, or the possibility of water droplets. A sin- gle sequence of scans took approximately 20 min during which time the sun altitude varied by up to a maximum of 5.2 degrees dependent upon time of day and location; this variation had minimal effect upon the results as evident from the standard errors of mean values for both irradiance and diffuse attenuation coefficient for downwelling irradiance, $K_{\mathrm{d}}$. The optical sensor was suspended on a frame which was positioned on a boom well clear of the boat and any shading effect. Current drag on the sensor and tilt was minimal.

Continuous record of UVR and other meteorological information. Instruments for the continuous recording of above surface ultraviolet irradiance and rainfall were located at Furanafushi and PMBC. At Furanafushi these were about $100 \mathrm{~m}$ from the experimental site, whilst at PMBC the instruments were $500 \mathrm{~m}$ from the PMBC pier site, and $10 \mathrm{~km}$ from the Ko Racha Yai location. UVR was recorded using $2 \pi$ cosine corrected broad-band sensors with a response curve centred on $316 \mathrm{~nm}$ and full bandwidth at halfmaximum response (FWHM) 303 to $329 \mathrm{~nm}$ (Macam Photometrics PD105B-Cos). The sensors were mounted to record downward global irradiance every minute with readings averaged and recorded every $10 \mathrm{~min}$ Cosine error was less than $+1.4 /-0.7 \%$ to $60^{\circ}$ (i.e. sun altitudes above $30^{\circ}$ ). Sensors output was calibrated against the spectroradiometer in units of absolute UVB irradiance (280 to $320 \mathrm{~nm}$ ). Rainfall was recorded hourly in order to help define conditions of turbidity and dissolved organic carbon (DOC) in the seawater at the time of underwater irradiance measurments.

Diffuse attenuation coefficient for downwelling irradiance, $K_{\mathrm{d}} . K_{\mathrm{d}}$ was calculated from the downwelling irradiance at each $2 \mathrm{~nm}$ wavelength step for the depth interval of $\mathrm{O}^{-}$to $5 \mathrm{~m}$ assuming an exponential reduction of irradiance in accordance with the relationship (Kirk 1994)

$$
E_{\mathrm{d}}(Z)=E_{\mathrm{d}}\left(0^{-}\right) \mathrm{e}^{-K_{\mathrm{d}} Z}
$$

where $E_{d}(Z)$ is the value of global downwelling irradiance at depth $Z \mathrm{~m}, E_{\mathrm{d}}\left(0^{-}\right)$is the value of global downwelling irradiance just below the surface and $K_{\mathrm{d}}$ is the average value of the diffuse attenuation coefficient for downwelling irradiance for the depth interval $0^{-}$to $Z \mathrm{~m}$.

The mean value of the ratio $E_{d}(5 \mathrm{~m}) / E_{d}\left(0^{-} \mathrm{m}\right)$ for all scans was used. Because of the difficulties in positioning the sensor just below the water surface and the highly variable signal obtained at such shallow depths due to wave glitter effects, $E_{\mathrm{d}}\left(0^{-}\right)$was computed from the above surface value assuming an irradiance transmittance through the air-sea interface $\left[E_{\mathrm{d}}\left(0^{-}\right) / E_{\mathrm{d}}\left(0^{+}\right)\right]$of $96 \%$ (windspeeds $<5 \mathrm{~m} \mathrm{~s}^{-1}$, atmospheric visibility $>5 \mathrm{~km}$, sun altitudes $>46^{\circ}$ ) (Gregg \& Carder 1990). 
To check the validity of the exponential function for the irradiance data over this depth range the mean percentage irradiance for each depth $0^{-}, 1,2,3,4$, and $5 \mathrm{~m}$ was $\mathrm{In}$ transformed and a least squares regression fitted (Baker \& Smith 1982) This was done for the minimum recorded wavelength and at $10 \mathrm{~nm}$ intervals in the UVB, $20 \mathrm{~nm}$ in UVA, and $30 \mathrm{~nm}$ over the PAR (photosynthetically active radiation) range. In all cases the value for $K_{d}$ obtained was comparable to the computed $5 \mathrm{~m}$ value and $\mathrm{R}^{2}>0.90$

Biological damage assessment. In order to assess the potential biological damage at depth, each sequence of 6 scans (above water, 1, 2, 3, 4, and $5 \mathrm{~m}$ ) was first normalised to the absolute irradiance at $320 \mathrm{~nm}$ recorded in the above water scan. This meant that the effect of changing power levels due to time of day, atmospheric conditions, etc., between scans and between sites could be ignored. A mean spectrum for each depth was then computed from all scan data at each location and weighted by the DNA-damage action spectrum (Setlow 1974) represented by

$$
\varepsilon_{\text {DNA }}(\lambda)=e^{1382(1.0 / D-1.0)}
$$

where $D=1.0+\mathrm{e}^{1 \hat{\lambda}-310 / 9}$ and $\lambda$ is wavelength.

Statistical analysis. Where comparisons have been made using parametric $t$-tests data were first checked for normality (Shapiro Wilk test) and homoscedasticity (Bartlett's test)

Symbols and units. Table 1 summarises the major symbols and units used in this paper.

\section{RESULTS}

\section{Continuous record of $\mathrm{UV}$ irradiance and rainfall}

The records of continuous UVR for the relevant days are shown in Fig 1. Sequences of spectroradiometer scans were only taken during stable periods of irradiance. In the $30 \mathrm{~d}$ preceding 7 July 1994, rainfall in the Maldives totalled $87 \mathrm{~mm}$ compared with a monthly average for this time of year of $168 \pm 15 \mathrm{~mm}$ ( $\mathrm{SE}, \mathrm{n}=26$ ). At PMBC rainfall was $11 \mathrm{~mm}$ in the $30 \mathrm{~d}$. prior to 10 February 1995, and nil between 10 and 21 February whilst mean monthly rainfall is normally $20 \pm 3 \mathrm{~mm}(\mathrm{n}=13)$. The seasonal weather pattern in the Maldives involves a reversing monsoon with southwesterly winds between the months of May and November accompanied by heavier rainfall and rougher seas; between December to April the wind direction reverses to the north east and rainfall decreases. Total annual rainfall is $1932 \pm 55 \mathrm{~mm}$ ( $\mathrm{n}=$ 26), ranging from a monthly maximum of 219 to a minimum of $48 \mathrm{~mm}$. A similar reversing monsoon pattern is experienced at $\mathrm{PMBC}$, with a wet south-west
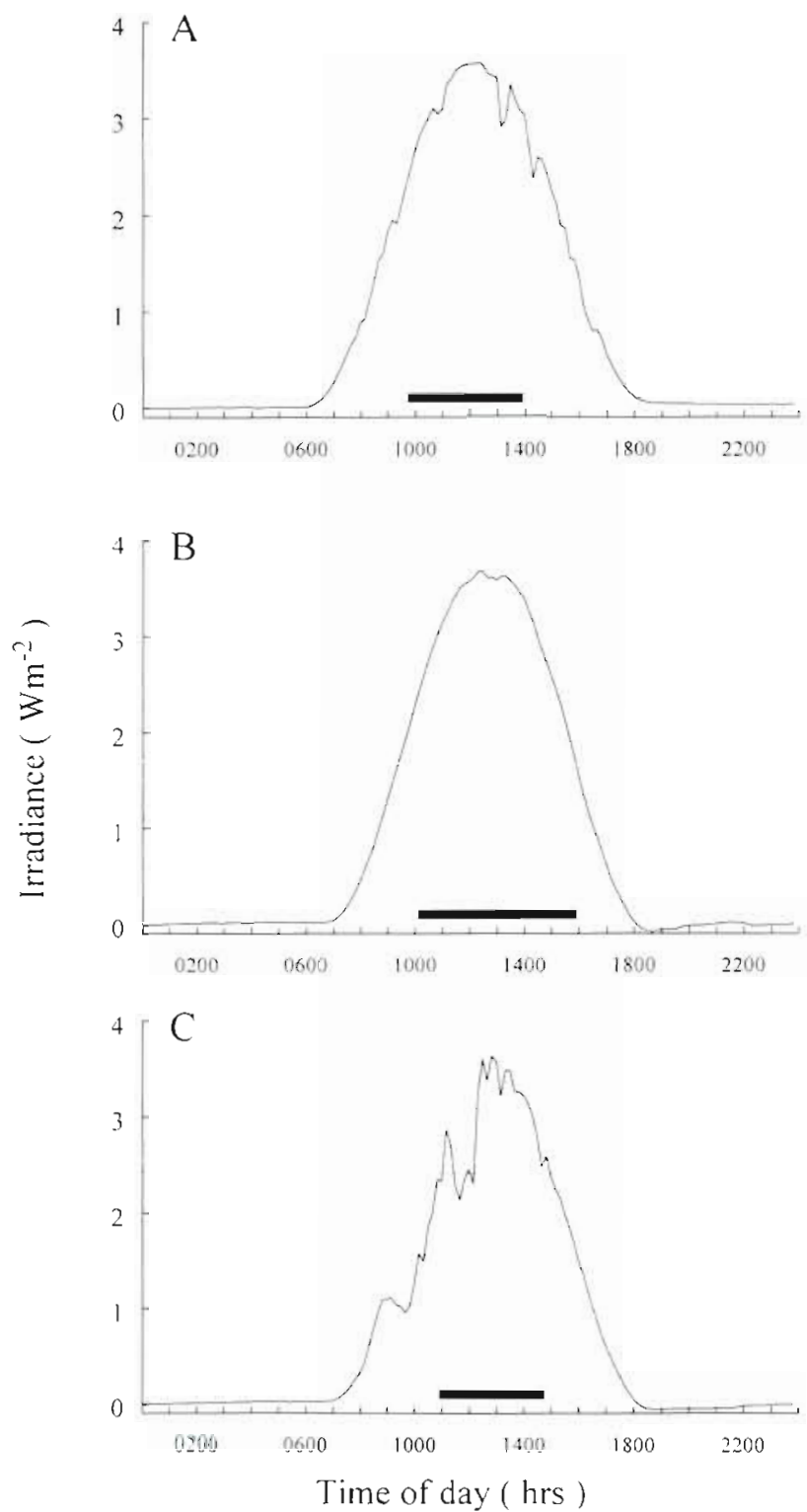

Fig. 1 Continuous record of above water global irradiance recorded from UVB broad-band sensors at (A) Furanafushi, Maldıves: 7 July 1994; (B) Phuket Marine Bıological Center (PMBC), Thailand: 10 February 1995; and (C) PMBC: 21 February 1995. Horizontal bars indicate the duration of daylight hours when underwater spectroradiometer scans were made

monsoon between May and October and a dry northeast monsoon from November to April. Annual mean rainfall is normally $2260 \pm 127 \mathrm{~mm}$, with a monthly maximum of 391 and minimum of $20 \mathrm{~mm}$. The rainfall data demonstrate that our measurements of UVR penetration underwater were taken during a relatively dry (Maldives) and exceptionally dry (Thailand) period of the year. Since rainfall plays an important part in terrigenous run-off, particularly at Phuket, it is likely that the suspended sediment and DOC levels in 
Table 1. Symbols and units used in this paper

\begin{tabular}{|c|c|c|}
\hline Symbol & Definition & Unit \\
\hline$\lambda$ & Wavelength & $\mathrm{nm}$ \\
\hline DOC & $\begin{array}{l}\text { Dissolved organic carbon. Synonymous with other commonly used terms, } \\
\text { 'yellow substance', 'Gelbstoff', 'Gilvin', and DOM (dissolved organic material) }\end{array}$ & \\
\hline$E_{\mathrm{DNA}}$ & $\begin{array}{l}\text { Global downwelling solar irradiance weighted by the Setlow (1974) } \\
\text { DNA-damage action spectrum }\end{array}$ & $W m^{-2}$ \\
\hline$E_{\mathrm{c}}$ & $\begin{array}{l}\text { Global downwelling solar irradiance (sum of direct and diffuse components of } \\
\text { downwelling irradiance) }\end{array}$ & $W m^{-2}$ \\
\hline$E_{\lambda}(\lambda)$ & Global downwelling solar irradiance at specified wavelength $\lambda$ & $W m^{-2} \mathrm{~nm}^{-1}$ \\
\hline$E_{d}(\lambda, Z)$ & Global downwelling solar irradiance at wavelength $\lambda$ and depth $Z$ metres & $W m^{-2} n^{-1}$ \\
\hline$E_{13}\left(\lambda, 0^{+}\right)$ & Global irradiance just above sea surface & $W m^{-2} \mathrm{~nm}^{-1}$ \\
\hline$F_{1}\left(\lambda, 0^{-}\right)$ & Global irradiance just below sea surface & $W m^{-2} n^{-1}$ \\
\hline IWHM & Full bandwidth at half maximum response & $\mathrm{nm}$ \\
\hline$K_{\mathrm{d}}$ & Diffuse attenuation coefficient for downwelling irradiance & $\mathrm{m}^{-1}$ \\
\hline PAR & Photosynthetically active radiation $(400-700 \mathrm{~nm})$ & $\mu \mathrm{mol}$ quanta $\mathrm{m}^{-2} \mathrm{~s}^{-1}$ \\
\hline UVA & Ultraviolet A radiation $(320-400 \mathrm{~nm})$ & \\
\hline UVB & Ultraviolet $\mathrm{B}$ radiation $(280-320 \mathrm{~nm})$ & \\
\hline UVR & Ultraviolet radiation $(280-400 \mathrm{~nm})$ & \\
\hline
\end{tabular}

Table 2. Percentage of above water global downwelling irradiance $\left[E_{d}\left(0^{+}\right)\right]$by waveband remaining at depths of $1,2,3,4$, and $5 \mathrm{~m}$ at each location. (Values in parentheses are SE of the mean)

\begin{tabular}{|c|c|c|c|c|c|c|c|c|c|}
\hline \multirow[t]{2}{*}{ Depth $(m)$} & \multicolumn{3}{|c|}{ Maldives: Furanafushi $(\mathrm{n}=7$ ) } & \multicolumn{3}{|c|}{ Thalland: Ko Racha Yai $(n=6)$} & \multicolumn{3}{|c|}{ Thailand: PMBC pier $(n=14)$} \\
\hline & UVB & UVA & PAR & UVB & UVA & PAR & UVB & UVA & PAR \\
\hline 1 & $58(2.3)$ & $73(1.5)$ & $81(2.2)$ & $44(2.2)$ & $67(2.5)$ & $77(4.2)$ & $25(1)$ & $45(1.1)$ & $70(1.2)$ \\
\hline 2 & $37(1)$ & $57(0.8)$ & $68(2.6)$ & $21(1.7)$ & $48(1.5)$ & $64(2.2)$ & $5(0.3)$ & $21(0.9\}$ & $47(1.2)$ \\
\hline 3 & $25(0.6)$ & $49(1)$ & $58(1.7)$ & $10(0.7)$ & $36(0.9)$ & $54(1.2)$ & $1.2(0.1)$ & $9\{0.6\}$ & $30(1.7)$ \\
\hline 4 & $17(0.7)$ & $40(1)$ & $48(1.6)$ & $4(0.3)$ & $26(1.1)$ & $47(1.4)$ & $0.2(0.03)$ & $4(0.3)$ & $20(1.3)$ \\
\hline 5 & $12(0.5)$ & $33(0.9)$ & $42(1.3)$ & $2(0.1)$ & $20(0.7)$ & $42(0.9)$ & $0.04(0.01)$ & $2(0.2)$ & $13(0.8)$ \\
\hline $\begin{array}{l}\text { Depth of } 1 \% \\
\text { irradiance }\end{array}$ & 11 & 21 & 26 & 6 & 14 & 26 & 3 & 5.8 & 11.5 \\
\hline
\end{tabular}

seawater were near or at their minimum. The conditions for maximum UVR penetration would, therefore, have been near optimal.

\section{Downwelling irradiance}

The percentage of $E_{d}$ remaining at each of the measured depths relative to the above water surface irradiance $\left(E_{d} 0^{+}\right)$is summarised in Table 2 . The most important features are the rapid attenuation of downwelling UVB irradiance even in the clear oceanic water at Furanafushi, $12 \%$ remaining at $5 \mathrm{~m}$ depth. In coastal waters, attenuation is even more pronounced, $2 \%$ at Ko Racha Yai, and a mere $0.04 \%$ in the turbid inshore water at the PMBC pier. Interestingly, although the turbid PMBC waters also showed a marked attenuation of PAR (13\% at $5 \mathrm{~m})$, there was no difference between PAR at Furanafushi (42\%) and Ko Racha Yai (42\%) ( $t$ test). An important implication from this result is that measurement of PAR alone cannot be used to predict attenuation of either UVA or UVB. If the data for Furanafushi are fitted to the exponential model for downwelling irradiance, the depth at which $1 \%$ of surface UVB remains is found to be $11 \mathrm{~m}$. The $1 \%$ depths for $\mathrm{Ko}$ Racha Yai and PMBC pier are 6 and $3 \mathrm{~m}$ respectively.

\section{Diffuse attenuation coefficient for downwelling irradiance}

The values of $K_{\mathrm{d}}$ for each site over the depth range $0^{-}$ to $5 \mathrm{~m}$ are shown in Fig. $2 \mathrm{~A}$ and tabulated in Table 3. None of the curves have been smoothed and the jagged nature of the curves for Furanafushi and Ko Racha Yai in the PAR is a function of wave focusing effects due to the narrow scan interval ( $2 \mathrm{~nm}$ ) and shallow depth. This effect disappears in the PMBC pier data due to the heavy attenuation and particulate scattering which produces a more diffuse underwater radiation profile.

Comparative plots of $K_{\mathrm{d}}$ for PAR and the longer wavelength UVR are shown in Fig. 2B from the deep 

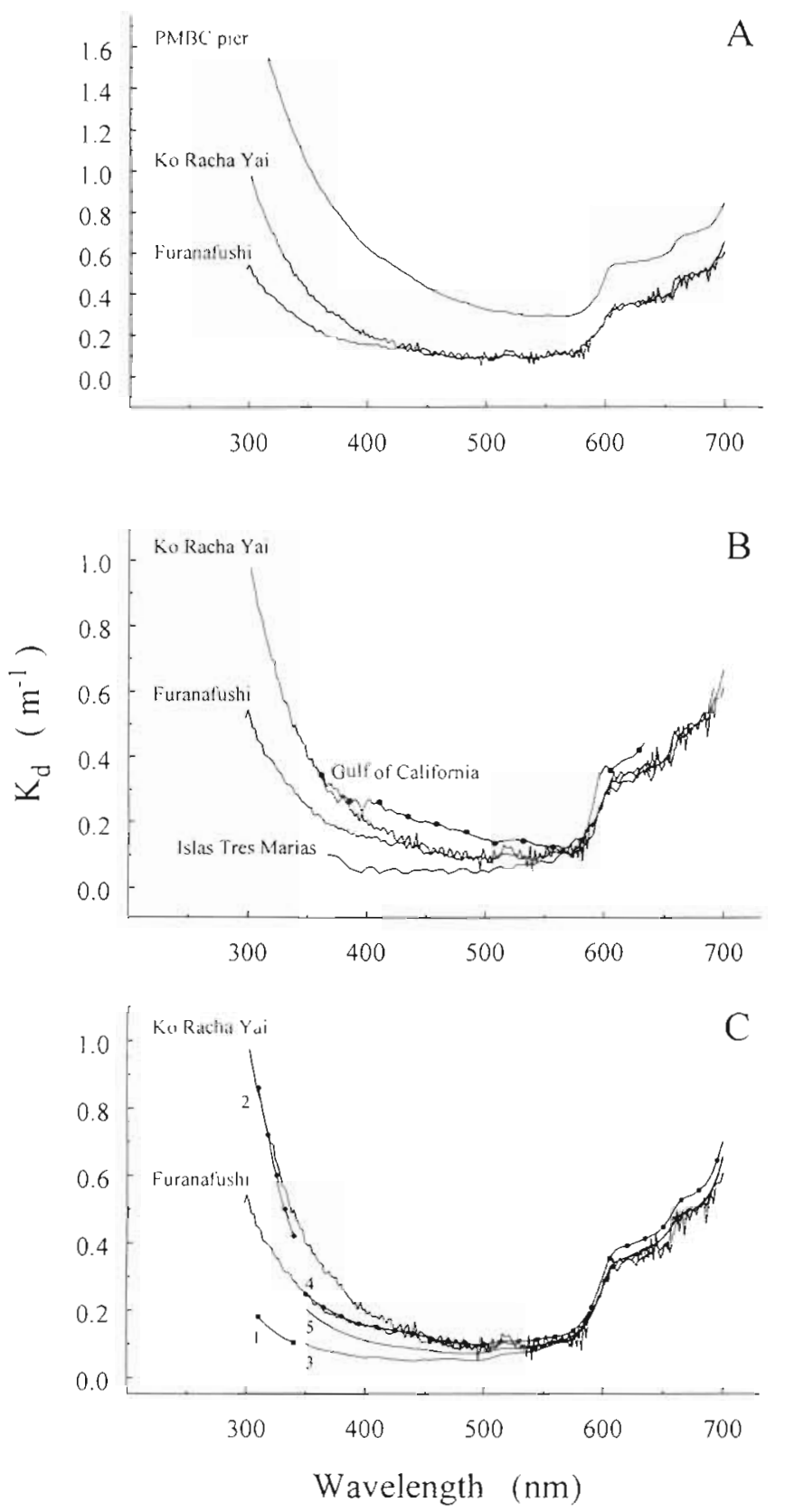

Fig. 2. Diffuse attenuation coefficient $\left(K_{d}\right)$ for downward irradiance for various water types as a function of wavelength. (A) Data for PMBC pier (inshore coastal), Ko Racha Yai (coastal island), Furanafushi (mid-ocean a toll lagoon). (B) Comparison of data with deep ocean measurements (350 to $700 \mathrm{~nm}$ ) of Tyler \& Smith (1970); Gulf of California, and Isla Tres Marias, Pacific Ocean. (C) Comparison with deep water UV measurements ( 310 to $340 \mathrm{~nm}$ ) of Smith \& Baker (1979) for (1) the Gulf of Mexico (ocean site), and (2) Tampa, Florida (coastal offshore); and measurements ( 350 to $700 \mathrm{~nm}$ ) of Maritorena \& Guillocheau (1996, pers. comm.) for French Polynesian coral reefs in the open ocean at (3) Moorea, in (4) the lagoon at Moorea, and in (5) the lagoon at Takapoto. In B and $C$ data for $\mathrm{PMBC}$ have been omitted to allow expanded $y$-axis scaling oceanic data of Tyler \& Smith (1970) where measurements were taken in the Gulf of California (water depth $160 \mathrm{~m}$ ) and off the Isla Tres Marias (Pacific Ocean, water depth $400 \mathrm{~m}$-'clear blue tropical water'). Data are for $5 \mathrm{~nm}$ intervals between the wavelengths 362 to $697 \mathrm{~nm}$, over a depth range of 5 to $10 \mathrm{~m}$. Similar comparisons are also made (Fig. 2C) with the data of Maritorena \& Guillocheau (1996, and pers. comm.), whose measurements were taken in shallower tropical waters close to the coral reefs of the high oceanic island of Moorea and the ocean atoll of Takapoto, French Polynesia. Maritorena \& Guillocheau's data covered the wavelengths 350 to $700 \mathrm{~nm}$ ( $5 \mathrm{~nm}$ intervals). The ocean subset was for 5 stations above the outer reef slope of Moorea, 11 in Moorea lagoon, and 5 in Takapoto lagoon. These data sets are the only comparable published measurements of PAR and longer wavelength UVR for tropical waters in the close vicinity of coral reefs.

Also compared in Fig. $2 \mathrm{C}$ are the only other published data sets for actual measurements in the UVB from Smith \& Baker (1979). Measurements were taken down to $310 \mathrm{~nm}$ at 2 stations; one in the middle of the Gulf of Mexico $\left(26^{\circ} 00^{\prime} \mathrm{N}, 89^{\circ} 00^{\prime} \mathrm{W}\right)$ described as 'clear ocean waters of low productivity', and the second from coastal waters north-west of Tampa, Florida $\left(28^{\circ} 38.5^{\prime} \mathrm{N}, 83^{\circ} 06.0^{\prime} \mathrm{W}\right)$ noted as being 'moderately productive ocean waters' with 'a relatively high concentration of dissolved organic material'.

\section{Biological damage potential}

No UVR damage action spectra exist at the whole organism level for corals or any other tropical sessile benthic organism. Two action spectra are commonly used in UVR radiation studies, the generalised plant action spectrum as defined by Caldwell (1971) and the DNA-damage action spectrum (Setlow 1974). Both spectra have common features, namely a maximum effect at the short wavelengths and a steep exponential decline above about $300 \mathrm{~nm}$. By definition the Caldwell function reduces to zero at $313.3 \mathrm{~nm}$ whereas the DNA-damage function continues to reduce exponentially with increasing wavelength. For the purpose of assessing the potential biological effect of the UVB irradiance at each depth, we have chosen the Setlow function as being more relevant but we have ignored the weighted irradiance above $320 \mathrm{~nm}$ since this contributes $<1 \%$ to the integrals in each case. Fig. 3 shows the transformed spectral data for each location at each depth, together with the total integral expressed as a percentage of the above water integral $(100 \%)$. These integrals can be compared to the UVB irradiance values given in Table 2. The main feature in each case is 
Table 3. Diffuse attenuation coefficient for downwelling irradiance $\left(K_{\mathrm{d}}\right)$. Values for UVB wavelengths are given at $2 \mathrm{~nm}$ intervals; UVA $4 \mathrm{~nm}$; and PAR $12 \mathrm{~nm}$

\begin{tabular}{|c|c|c|c|c|c|c|}
\hline \multirow{2}{*}{$\begin{array}{l}\text { Wavelength } \\
\qquad(\mathrm{nm})\end{array}$} & \multicolumn{2}{|c|}{ Furanafushi } & \multicolumn{2}{|c|}{ Ko Racha Yai } & \multicolumn{2}{|c|}{ PMBC pier } \\
\hline & Mean & SE & Mean & SE & Mean & $\mathrm{SE}$ \\
\hline 298 & 0.518 & 0.036 & & & & \\
\hline 300 & 0.544 & 0.023 & & & & \\
\hline 302 & 0.519 & 0.019 & 0.976 & 0.019 & & \\
\hline 304 & 0.485 & 0.031 & 0.938 & 0.021 & & \\
\hline 306 & 0.487 & 0.027 & 0.902 & 0.014 & & \\
\hline 308 & 0.450 & 0.011 & 0.858 & 0.017 & & \\
\hline 310 & 0.445 & 0.013 & 0.837 & 0.018 & & \\
\hline 312 & 0.437 & 0.016 & 0.815 & 0.014 & & \\
\hline 314 & 0.405 & 0.011 & 0.780 & 0.019 & & \\
\hline 316 & 0.402 & 0.007 & 0.752 & 0.016 & 1.548 & 0.026 \\
\hline 318 & 0.396 & 0.013 & 0.727 & 0.020 & 1.512 & 0.027 \\
\hline 320 & 0.389 & 0.010 & 0.696 & 0.015 & 1.479 & 0.027 \\
\hline 324 & 0.366 & 0.012 & 0.648 & 0.010 & 1.399 & 0.025 \\
\hline 328 & 0.348 & 0.010 & 0.601 & 0.019 & 1.336 & 0.025 \\
\hline 332 & 0.316 & 0.011 & 0.565 & 0.016 & 1.274 & 0.025 \\
\hline 336 & 0.311 & 0.007 & 0.523 & 0.015 & 1.211 & 0.024 \\
\hline 340 & 0.285 & 0.008 & 0.498 & 0.010 & 1.160 & 0.025 \\
\hline 344 & 0.270 & 0.005 & 0.462 & 0.011 & 1.108 & 0.024 \\
\hline 348 & 0.258 & 0.009 & 0.438 & 0.009 & 1.049 & 0.024 \\
\hline 352 & 0.243 & 0.010 & 0.389 & 0.013 & 1.010 & 0.022 \\
\hline 356 & 0.220 & 0.007 & 0.366 & 0.013 & 0.968 & 0.023 \\
\hline 360 & 0.222 & 0.010 & 0.353 & 0.016 & 0.921 & 0.022 \\
\hline 364 & 0.203 & 0.008 & 0.337 & 0.017 & 0.891 & 0.022 \\
\hline 368 & 0.193 & 0.006 & 0.309 & 0.006 & 0.852 & 0.021 \\
\hline 372 & 0.187 & 0.008 & 0.299 & 0.008 & 0.816 & 0.021 \\
\hline 376 & 0.178 & 0.011 & 0.297 & 0.013 & 0.790 & 0.021 \\
\hline 380 & 0.178 & 0.009 & 0.279 & 0.015 & 0.759 & 0.020 \\
\hline 384 & 0.173 & 0.009 & 0.251 & 0.009 & 0.730 & 0.020 \\
\hline 388 & 0.161 & 0.010 & 0.235 & 0.020 & 0.699 & 0.019 \\
\hline 392 & 0.154 & 0.007 & 0.226 & 0.018 & 0.670 & 0.019 \\
\hline 396 & 0.158 & 0.009 & 0.228 & 0.005 & 0.645 & 0.017 \\
\hline 400 & 0.149 & 0.007 & 0.204 & 0.015 & 0.627 & 0.018 \\
\hline 412 & 0.139 & 0.008 & 0.172 & 0.010 & 0.574 & 0.018 \\
\hline 424 & 0.134 & 0.008 & 0.146 & 0.008 & 0.530 & 0.017 \\
\hline 436 & 0.139 & 0.007 & 0.159 & 0.006 & 0.487 & 0.017 \\
\hline 448 & 0.102 & 0.014 & 0.133 & 0.011 & 0.439 & 0.016 \\
\hline 460 & 0.100 & 0.010 & 0.101 & 0.009 & 0.405 & 0.015 \\
\hline 472 & 0.094 & 0.010 & 0.109 & 0.008 & 0.374 & 0.014 \\
\hline 484 & 0.092 & 0.010 & 0.114 & 0.006 & 0.355 & 0.014 \\
\hline 496 & 0.096 & 0.007 & 0.047 & 0.010 & 0.331 & 0.013 \\
\hline 508 & 0.087 & 0.005 & 0.117 & 0.011 & 0.316 & 0.012 \\
\hline 520 & 0.101 & 0.010 & 0.120 & 0.010 & 0.306 & 0.011 \\
\hline 532 & 0.092 & 0.011 & 0.082 & 0.017 & 0.294 & 0.012 \\
\hline 544 & 0.080 & 0.013 & 0.073 & 0.018 & 0.291 & 0.012 \\
\hline 556 & 0.107 & 0.011 & 0.091 & 0.022 & 0.294 & 0.011 \\
\hline 568 & 0.105 & 0.009 & 0.100 & 0.014 & 0.289 & 0.012 \\
\hline 580 & 0.150 & 0.010 & 0.138 & 0.018 & 0.311 & 0.012 \\
\hline 592 & 0.203 & 0.016 & 0.203 & 0.022 & 0.384 & 0.013 \\
\hline 604 & 0.314 & 0.022 & 0.280 & 0.027 & 0.532 & 0.014 \\
\hline 616 & 0.339 & 0.017 & 0.344 & 0.020 & 0.548 & 0.013 \\
\hline 628 & 0.367 & 0.019 & 0.330 & 0.022 & 0.559 & 0.015 \\
\hline 640 & 0.364 & 0.019 & 0.414 & 0.017 & 0.574 & 0.014 \\
\hline 652 & 0.398 & 0.012 & 0.399 & 0.023 & 0.600 & 0.015 \\
\hline 664 & 0.466 & 0.022 & 0.429 & 0.025 & 0.676 & 0.015 \\
\hline 676 & 0.493 & 0.017 & 0.497 & 0.037 & 0.703 & 0.015 \\
\hline 688 & 0.532 & 0.013 & 0.513 & 0.016 & 0.733 & 0.015 \\
\hline 700 & 0.659 & 0.017 & 0.608 & 0.037 & 0.848 & 0.016 \\
\hline
\end{tabular}



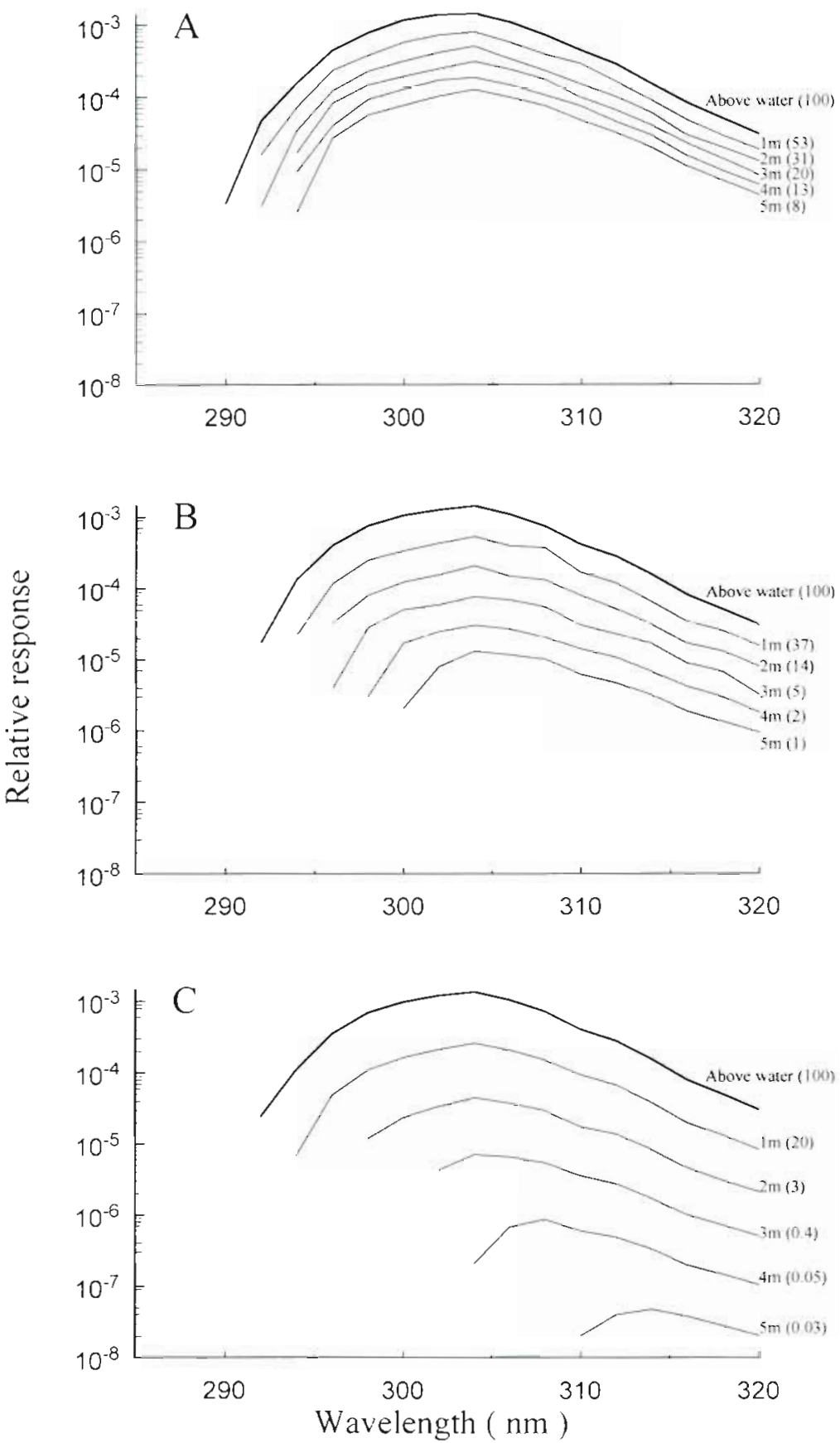

Fig. 3. Global downwelling UVB irradiance $\left(E_{\mathrm{d}}\right)$ at depths $0^{*}, 1,2,3,4$, and $5 \mathrm{~m}$ transformed by the Setlow (1974) DNA-damage action spectrum. (A) Furanafushi, Maldives, (B) Ko Racha Yai, Thailand, and (C) PMBC pier, Thailand. Values in brackets are integrals expressed as percentage of above water $\left(0^{+} \mathrm{m}\right)$ spectrum

that the damage potential reduces more rapidly with increasing depth compared to the UVB irradiance. This is due to the greater attenuation of the shorter compared to the longer wavelengths by the seawater, shown by the rapid rise in $K_{d}$, which is further enhanced by the increase in damage potential as wavelength decreases. A $1 \%$ damage potential depth may also be calculated for each of the water types by assuming an exponential function, a relationship which is valid in each case $(p<0.0001)$. The $E_{\text {DVA }} 1 \%$ depths are 9 m for Furanafushi, $4.7 \mathrm{~m}$ at Ko Racha Yai and $2.6 \mathrm{~m}$ at PMBC pier

\section{DISCUSSION}

The results illustrate the rapid attenuation of solar UV radiation underwater even in the clear oceanic water of the Maldive islands. The Maldive waters fall midway between the deep oceanic waters off Moorea, the Gulf of Mexico, and the Pacific Ocean (Islas Tres Marias), which all have very similar $K_{d}$ values, and the coastal waters of Tampa (Florida) or the Gulf of California (Fig. 2). It should be noted that the values of $K_{\mathrm{d}}$ for the deep ocean sites were within $20 \%$ of the clearest open ocean waters where productivity is very low (Smith \& Baker 1979). Fig. 2C also shows that the attenuation of UVB in the Maldives is likely to be very similar to the lagoon waters at Moorea, as demonstrated by the overlap of curves in the waveband 350 to $400 \mathrm{~nm}$. The lagoon waters at Takapoto, which are 'extremely oligotrophic and clear' (Salvat \& Richard 1985), would appear to have lower UVB attenuation than the Maldives but the curves show some convergence towards the shorter UV wavelengths. The importance of these similarities is that even at mid-ocean atoll and high island sites with their clear tropical waters UVB attenuation is relatively high with only $1 \%$ of surface UVB penetrating to depths of $11 \mathrm{~m}$. These results may also be compared with approximate values computed from the data of Glynn (1993) who recorded UVB using a narrow band interference filter sensor (FWHM 290 to $301 \mathrm{~nm}$ ) on a nearshore coral reef at Motobu-cho, Okinawa where the $1 \%$ depth was $14.5 \mathrm{~m}$. A $1 \%$ depth of $30 \mathrm{~m}$ similarly computed for San Salvador, Bahamas (UVB data of Gleason \& Wellington 1993-but see 'Introduction' of this paper for discussion on data from LI-1800UW instruments) probably represents extreme conditions of optimum water clarity for any coral reef site, and is comparable to deep open ocean waters. 
Where coral reefs grow closer to larger land masses (i.e. in much of South East Asia), the results from Ko Racha Yai indicate that UVB attenuation underwater will be much higher so that the $1 \%$ depth is now reduced to $6 \mathrm{~m}$ or less. This is supported by Smith \& Baker's (1979) data from Tampa coastal waters. The measurements at PMBC pier undoubtedly represent an extreme of inshore water turbidity with high UVB attenuation $(1 \%$ depth $3 \mathrm{~m})$

These results are hardly surprising since it has long been recognised that DOC is the principal absorber of shortwave solar radiation in seawater (Baker \& Smith 1982, Dera 1992). The origins and nature of the various components of DOC have been reviewed in Kirk (1994) and Dera (1992). Its presence in deep oceanic waters is attributed to recent breakdown of phytoplankton and a more stable component of much greater age, possibly of terrestrial origin. Closer to land masses, DOC concentrations increase as a result of fluvial discharge and anthropogenic activities (Bricaud et al. 1981). Included in a group of terrestrial derived substances which actively absorb solar ultraviolet are the humic and fulvic acids, which are frequently found incorporated in coral skeletons. The resultant fluorescent banding patterns have been linked to seasonal rainfall patterns over land and the subsequent freshwater discharge to adjacent coral reefs (Isdale 1984). The water types measured in this study probably represent an average range of water types in which many coral reefs exist; these range from the low DOC environment found in atoll and other offshore island locations, to the greater DOC load in tropical seawater above the extensive fringing reefs of South East Asia and other reefs under the influence of terrestrial runoff or anthropogenic activities. Furthermore it may be concluded from the rainfall patterns in the $30 \mathrm{~d}$ prior to measurements, all of which were low compared to the annual maximum monthly rainfall, that the input of DOC from terrestrial run-off would have been the lowest likely to be experienced both seasonally and between years

The observation that the PAR integral of spectral irradiance did not differ between Furanafushi and Ko Racha Yai is important. PAR irradiance underwater has yet to be shown to reach levels which cause photoinhibition in corals (Falkowski et al. 1990) whilst the biologically damaging effect of the shorter wavelengths of UVR are well recognised and include the direct effects of UVB (for review see Holm-Hansen et al. 1993) and possibly some effects of UVA mediated through reactive oxygen species (Tyrell 1991). The fact that the PAR integral did not differ whilst attenuation of UVR was much greater at Ko Racha Yai leads to the conclusion that solar radiation conditions for coral growth are better in the less hostile UVB environment of coastal waters than at mid-ocean sites. This result is counter-intuitive to that which might be reached by visual observation and deduction, namely that deep blue water represents optimum solar radiation conditions. Furthermore, proposals that simple Secchi disc measurements could be used to predict UVB conditions (Calkins 1982) are cast into doubt, and further restrict the function of this technique solely to providing a simple visual index of water clarity (Preisendorfer 1986, Kirk 1994)

When the potential biological damage of the UVB is considered, the effective penetration depth is reduced in all of the water types studied. If tidal ranges are also taken into account, a further interesting observation may be made. At sites in Thailand, tidal range varies between $0.6 \mathrm{~m}$ at neaps to $3.1 \mathrm{~m}$ at springs. Corals at Phuket are regularly exposed on spring tides throughout the year to above water daytime solar irradiance (Brown et al. 1994). At such times they will experience up to 20 -fold changes in UVB irradiance or 33 -fold changes in the potential DNA damage effect in the space of $4 \mathrm{~h}$ (2 $\mathrm{m}$ submerged in the late morning to subaerial exposure in the early afternoon). Their ability to withstand such variations suggests that shallow water corals can protect themselves very effectively either through behavioural mechanisms (e.g polyp retraction) or biochemical/physiological adaptations (e.g. protective pigments) (see Brown 1996 for review). Indeed it seems that in intertidal corals high PAR irradiance (possibly in addition to UVR), rather than UVB. is responsible for inducing specific damage such as solar bleaching in corals (Brown et al. 1994. Dunne 1994, authors' unpubl.).

Acknowledgements. We are particularly grateful to Dr $T \mathrm{P}$ Scoffin for his field assistance in the Maldives and to Dr S. Maritorena for access to his data for French Polynesia. The Thailand phase was assisted by our friends at PMBC led by Dr Hansa Chansang and with the indispensable help of $\mathrm{Mr}$ Ukkrit Satapoomin. This research was part of a wider programme of research funded by the Natural Resources and Environment Department of the Overseas Development Administration of the United Kingdom.

\section{LITERATURE CITED}

Baker KS, Smith RC (1982) Spectral irradiance penetration in natural waters. In: Calkins J (ed) NATO Conference Series, IV, Manne sciences: the role of solar ultraviolet radiation in marune ecosystems, 7 Plenum Press, New York, p 233-246

Bricaud A, Morel A, Prieur L (1981) Absorption by dissolved organic matter of the sea (yellow substances) in the UV and visible domains. Limnol Oceanogr 26:43-53

Brown BE (1996) Adaptations of reef corals to physical environmental stress. Adv Mar Biol (in press)

Brown BE, Dunne RP (1988) The environmental impact of coral mining on coral reefs in the Maldives. Environ Conserv 15:159-166 
Brown BE, Dunne RP, Scoffin TP, Le Tissier MDA (1994) Solar damage in intertidal corals. Mar Ecol Prog Ser 105: $219-230$

Caldwell MM (1971) Solar UV irradiation and the growth and development of higher plants. In: Giese AC (ed) Photophysiology, 6. Academic Press, New York, p 131-177

Calkins J (1982) A method for the estimation of the penetration of biologically injurous solar ultraviolet radiation into natural waters. In: Calkins J (ed) NATO Conference Series, IV, Manne sciences: the role of solar ultraviolet radiation in marine ecosystems, 7 Plenum Press, New York, p 247-261

Dera J (1992) Elsevier oceanography series, Vol 53, Marine physics. Elsevier Science Publishing Company, Amsterdam

Dunne RP (1994) Radiation and coral bleaching. Nature 368: 697

Falkowski PG, Jokiel PL, Kinzie RA (1990) Irradiance and corals. In: Dubinsky $Z$ (ed) Ecosystems of the world coral reefs, 25. Elsevier Science Publishing Company, New York, p 89-107

Fleischmann EM (1989) The measurement and penetration of ultravinlet radiation into tropical marine water Limnol Oceanogr 34:1623-1629

Fraser AB, Walker RE, Jurgens FC (1980) Spatial and temporal correlation of underwater sunlight fluctuations in the sea. IEEE J Ocean Eng 5:195-198

Gardiner BG, Webb AR, Bais AF, Blumthaler M, Dirmhirn P, Forster D, Gillotay D, Henriksen K, Huber M, Kirsch PJ, Simon PC, Svenoe T, Weihs P, Zerefos CS (1993) European intercomparison of ultraviolet spectroradiometers. Environ Technol 14:25-43

Gleason DF (1993) Differential-effects of ultraviolet-radiation on green and brown morphs of the Caribbean coral Porites astreoides. Limnol Oceanogr 38:1452-1463

Gleason DF, Wellington GM (1993) Ultraviolet radiation and coral bleaching. Nature 365:836-838

Glynn PW (1993) Coral-reef bleaching-ecological perspectives. Coral Reefs 12:1-17

Gregg WW, Carder KL (1990) A simple spectral solar irradiance model for cloudless maritıme atmospheres. Limnol Oceanogr 35:1657-1675

Holm-Hansen O, Lubin D, Helbling EW (1993) Ultraviolet radiation and its effects on organisms in aquatic environments. In: Young AR, Björn LO, Moan J, Nultsch W (eds) Environmental UV photobiology. Plenum Press, New York, p 379-425

Isdale $\mathrm{P}$ (1984) Fluorescent bands in massive corals record centuries of coastal rainfall. Nature 310:578-579

Kirk JTO (1994) Light and photosynthesis in aquatic ecosys. tems, 2nd edn. Cambridge University Press, Cambridge

Kirk JTO, Hargreaves BR, Morris DP, Coffin RB, David B,

This article was presented by O. Holm-Hansen (Senior

Editorial Advisor), La Jolla, California, USA
Fredrickson D, Karentz D, Lean DRS, Lesser MP, Madronich S, Morrow JH, Nelson NB, Scully NM (1994) Measurement of UV-B radiation in freshwater ecosystems.

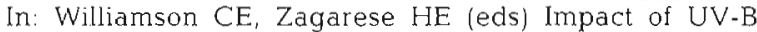
radiation on pelagic freshwater ecosystems, Vol 43, Ergebnisse der Limnologie. Schweizerbart, Stuttgart, p $71-99$

Lesser MP (1996) Acclimation of phytoplankton to UV-B radiation: oxidative stress and photoinhibition of photosynthesis are not prevented by UV-absorbing compounds in the dinoflagellate Prorocentrum micans. Mar Ecol Prog Ser 132:287-297

Maritorena S, Guillocheau N (1996) Optical properties of water and spectral light absorption by living and non-liv. ing particles and by yellow substances in coral reef waters of French Polynesia. Mar Ecol Prog Ser 131:245-255

Matteucci R, Russo A (1985) Principali facies a coralli nell'atollo di North Malé (Isole Maldive). Boll Soc Geol Ital 104:311-326

Pressendorfer RW (1986) Secchi disc science: visual optics of natural waters. Limnol Oceanogr 31:909-926

Salvat B. Richard G (1985) Takapoto Atoll, Tuamotu Archipelago. Proc 5th Int Coral Reefs Congr 1:325 377

Scoffin TP, Tudhope AW, Brown BE, Chansang $H$, Cheeney RF (1992) Patterns and possible environmental controls of skeletogenesis of Porites Iutea, South Thailand. Coral Reefs 11:1-11

Setlow RB (1974) The wavelengths in sunlight effective in producing skin cancer a theoretical analysis. Proc Nat Acad Sci 71:3363-3366

Shick JM, Lesser MP, Dunlap WC, Stochaj WR, Chalker BE, Wu Won J (1.995) Depth-dependent responses to solar ultraviolet radiation and oxidative stress in the zooxanthellate coral Acropora microphthalma. Mar Biol 122: $41-51$

Smith RC, Baker KS (1979) Penetration of UVB and biologically effective dose-rates in natural waters. Photochem Photobiol 29:311-323

Smith RC, Baker KS (1981) Optical properties of the clearest natural waters (200-800 nm). Appl Optics 20:177-184

Tyler JE, Smith RC (1970) Measurement of spectral irradiance underwater. Gordon and Breach Science Publishers, New York

Tyrell RM (1991) UVA (320-380 nm) radiation as an oxidative stress. In: Sies Hi (ed) Oxidative stress: oxidants and antioxidants. Academic Press, London, p 57-83

Webb AR (1985) Solar uItra-violet radiation and vitamin D synthesis in man. PhD thesis, University of Nottingham

Webb AR, Gardiner BG, Blumthaler M, Forster P, Huber M, Kirsch PJ (1994) A laboratory investigation of two ultraviolet spectroradiometers. Photochem Photobiol 60: $84-90$

Manuscript first recelved: April 17, 1996

Revised version accepted: September 24, 1996 